\title{
DIAGNOSIS OF TOXOCARA VITULORUM INFECTION (ASCARIDIDA: NEMATODA): USING SELECTED PURIFIED ANTIGENS
}

\section{By}

OLFAT A. MAHDY ${ }^{1}$, WAHEED M. MOUSA ${ }^{1}$, MORSY RATEB GENEIDY ${ }^{2}$, SAHAR ZAYIED ABDEL-MAWGOOD ${ }^{1}$, AND SHIMAA ABDEL-RADI ${ }^{1}$

Departments of Parasitology ${ }^{1,2}$, Faculty of Veterinary Medicine, Cairo University ${ }^{1}$, Giza, P.O. Box 12211, and Faculty of Medicine, Al-Azhar University ${ }^{2}$, Nasr City,

Egypt ( ${ }^{*}$ Correspondence: dr.olfat.mahdy@cu.edu.eg)

\section{Abstract}

Toxocara vitulorum is a nematode parasite of small intestine of buffaloes, particularly young age calves, causing economic and public health problems. Evaluation of the immunogenicity and diagnostic sensitivity of three selected $T$. vitulorum antigens include excretory secretary antigens (ESAg), Pre-enteric Ag (PeAg) and embryonated egg Ag (EEAg) were evaluated on the experimental and field level. PeAg appears as the most sensitive antigen in specific detection of anti-T.vitulorum antibodies (ATVAb). In inspected sera using ELISA Fractionation of the three T. vitulorum antigens using SDS-PAGE and determination of the specific fractions using EITB versus rabbit-hyper-immune sera (RHIS) and natural infected buffaloes and calve sera revealed that the bands corresponding to M.W of $105,90,67,19 \& 11 \mathrm{kDa}$ reacted specifically. Marked specific reaction even with sera from animals infected by low eggs/gram was recorded versus the fraction of $67 \mathrm{kDa}$ in the fractionated PeAg. This work identified this protein fraction as the most specific and sensitive one can be used for routine diagnosis on the field level.

Keywords: T. vitulorum, ELISA, SDS-PAGE, EITB, ESAg, PeAg, EEAg.

\section{Introduction}

Toxocara vitulorum is a parasite of large ruminants worldwide many tropical and subtropical countries (Rast et al, 2014), with a high prevalence in Egyptian cattle and buffaloes calves (Sultan et al, 2015). It is responsible for high morbidity and mortality rates resulting in serious economic losses and zoonotic importance (Omar and Lewis, 1993). Humans become infected by ingestion of infective eggs either from soil, dirty hands, raw fruits and vegetables or larvae from undercooked meat and unpasteurized milk (Borecka et al, 2010). Migration of the larvae through tissues produces severe inflammatory reactions and consequently to a wide range of pathological and clinical manifestations (Strube et al, 2013). Coprological examination techniques fail to detect infection in adult buffaloes and also during the prepatent stage and in mild infections. So in case of absence of parasitological evidence of infection, the immunological methods considered to be the only available way for diagnosis of infection (Jyoti et al, 2011). Serological tests based on immunological techniques Such as ELISA were recognized as the most effective approach for laboratory diagnosis of toxocariasis, (Fillaux and Magnaval (2013). Also, SDS-PAGE and western blotting considered more beneficial in identification of specific Toxocara spp. diagnostic or immunogenic protein fractions (Pinelli et al, 2013). Several Toxocara antigens were extracted by many authors and diagnostic values were determined by ESAg (StarkeBuzetti and Ferreira (2006), EEAg (El-Askalany et al, 2008), and PeAg (Jyoti et al, 2011)

The present study aimed to evaluate three Toxocara vitulorum antigens (ESAg, PeAg \& EEAg) in diagnosis of T. vitulorum on the suspected level and known infected ones. Fractionation of antigens was performed using SDS-PAGE followed by EITB techniques to determine the most specific diagnostic KDa antigenic fractions on field level to diagnose zoonotic visceral larva migrans.

\section{Material and Methods}

All the steps and procedures were approved by the Institutional Animal Care and Use ethical Committee (CU-IACUC), Cairo University (CU/ II/ S/ 2016/ 2017).

$T$. vitulorum antigens: Intact, active $T$. vit- 
ulorum adult worms were collected from intestine of freshly slaughtered buffalo calves in Cairo Governmental Abattoir. Worms were well washed in normal saline solution to prepare ESAg and peAg. T. vitulorum eggs were collected from the uteri distal part of adult females then embryonated for preparation of EEAg and induction of infection of rats(Starke and Ferreira, 2006).

T. vitulorum execratory/ secretory antigen (ESAg): ESAg was collected after incubation of active adult worms at $37^{\circ} \mathrm{C}$ for $2 \mathrm{hrs}$ in PBS supplemented with antibiotic. The fluid was centrifuged at 460xg for 5 minutes and the supernatant was filtered (Amerasinghe et al, 1992). The protein content was increased by concentration using polyethylene glycol in molecular porous membrane tubing 6-8 MW cut off (Spectrum Medical Inc., Los Angeles, CA 900060) at $4^{\circ} \mathrm{C}$ (Goswami et al, 2013). The concentrated fluid was collected and its protein content was measured using Lowry's Assay (1951) then stored at $-20^{\circ} \mathrm{C}$ till use.

$T$. vitulorum perienteric fluid antigen (PeAg): PeAg was collected from adult active $T$. vitulorum by puncturing the posterior end of each parasite with needle and perienteric fluid was drained, collected and centrifuged at 460xg for 5 minutes then treated as ESAg (Ferreira and Starke-Buzetti, 2005).

Embryonated eggs antigen (EEAg): EEAg was prepared from the previous embryonated $T$. vitulorum eggs after several washing with 0.01 PBS (PH 7.4) by centrifugation at 1500 r.p.m. for 3 minutes. Sediment eggs were mixed with an equal volume of the same solution then homogenized at 6000 r.p.m for 5 minutes in an ice bath. Homogenized sample was sonicated for 5 minutes at 5 pulse rate and 60-80 amplitude value using Coleparmer Ultrasonic homogenizer then suspension was subjected to high speed centrifugation at $14,000 \mathrm{rpm}$ for 30 minutes at $4^{\circ} \mathrm{C}$ and the supernatant was separated as EEAg, concentrated and its protein contents was measured and stored (El-Askaalany et $a l, 2008)$.
Production of hyper-immune sera in rabbits (RHIS): The method adopted was that of Tang et al. (2015), with little modification. The prepared $T$. vitulorum antigens (ESAg, PeAg \& EEAg) were used to produce hyperimmune sera. Sera were collected before immunization as negative sera. Three rabbits for each antigens were immunized subcutaneously with $1.2 \mathrm{mg}$ protein of $T$. vitulorum antigens, emulsified 1:1 with mineral oil. After 2 weeks another $1.2 \mathrm{mg}$ protein was mixed $1: 1$ in the oil and divided into 3 doses (day 14, $21 \& 28$ ) then injected subcutaneously. One week after the last immunization; rats were bled for sera and antibodies level was measured, and stored at $20^{\circ} \mathrm{C}$ until used as positive sera.

Tested sera: Fifteen natural infected buffaloes and 15 natural infected buffaloes-calves sera from three different levels of eggs/gram as well as 10 non-infected buffaloes and calve sera were used to evaluate antigens.

ELISA: Assay was done after Liu et al. (2015) with little modification. Optimal dilutions of various reagents were determined using Checkerboard titration. Microtitration polystyrene plates, 96- well, was coated with $4 \mu \mathrm{g}$ protein $/ \mathrm{ml}$ from each of the 3 tested antigen in coating buffer $(200 \mu \mathrm{l} /$ well $)$, incubated overnight at $4^{\circ} \mathrm{C}$. Plates were washed three times with washing buffer $(0.05 \%$ Tween-20 in PBS pH 7.3) then blocked using $0.5 \%$ bovine serum albumin in PBSTween-20 $(200 \mu 1 /$ well $)$ and incubated at $37^{\circ} \mathrm{C}$ for an hour. After washing reagents $(100 \mu \mathrm{l} /$ well $)$ were added and plates incubated at $37^{\circ} \mathrm{C}$ for an hour with shaking and washing after each step: tested and control serum samples (1:100 dilution). Protein A horse reddish peroxidase conjugate $(1: 1000$ in PBS) was detected by adding $100 \mu \mathrm{l} /$ well of substrate o-phenylenediamine dihydrochloride (OPD), plus $\mathrm{H}_{2} \mathrm{O}_{2}$ for 30 minutes and stopped by adding $50 \mu \mathrm{l} /$ well of $1 \mathrm{~N} \mathrm{H}_{2} \mathrm{SO}_{4}$. Optical densities (O.D) were read at $450 \mathrm{~nm}$ with a micro-ELISA reader system. Sera were considered positive when absorbance values were as or more than the cut off value 
(cut off $=$ double fold of mean negative control sera).Test evaluated diagnostic efficacy of antigens versus positive and negative RHIS as well as suspected field collected samples. Fractionation of antigens \& transferring of protein: SDS-PAGE analysis of 3 tested antigens under reduced conditions was done using $12 \%$ non-gradient slab gel with stacking gel5\%. Samples were electrophoresed at $20 \mathrm{~mA}$ current (Laemmli et al, 1970). Gel was shifted to coomassei blue stain and calibrated with marker in range of 230-10 KDa. Gel proteins were transferred at $10 \mathrm{~V}, 100 \mathrm{~mA}$ overnight at $4^{\circ} \mathrm{C}$, onto nitrocellulose paper (Towbin et al, 1979). Sheet was dried and stored until use.

Determination of specific protein fractions using EITB: Each T. vitulorum antigen was tested versus own RHIS to detect specific protein fraction. Also antigens were tested versus positive sera of buffaloes showed no eggs in feces and infected buffaloes and buffalo calves had eggs in feces to detect specific band to diagnose field infection. A longitudinal $\mathrm{NC}$ strips $(15 \times 0.5 \mathrm{~cm})$ with the fractionated antigens were cut out. Nonspecific binding of antibodies was blocked by incubating the strips with 3\% BSA TNT at $37^{\circ} \mathrm{C}$ for $1 \mathrm{~h}$. After blocking, strips were incubated versus known positive and negative control sera at 1:100 dilution, $0.5 \mathrm{ml}$ of sera/strip for 2 hours using Western-blot assay (Towbin et al, 1979). After washing, NC strips were exposed to 1:1,000 HRPconjugated IgG (Sigma, USA), diluted in blocking buffer, at $37^{\circ} \mathrm{C}$ for $1 \mathrm{~h}$. Peroxidase substrate (4-chloro-1-naphthol) was added to reveal IgG/ antigen interaction. Protein fractions positively reacted with positive control sera, and negatively with negative control one as specific protein fractions.

\section{Results}

All T. vitulorum antigens were sensitive for $\mathrm{ATV}-\mathrm{Ab}$ in the infected animals' sera. PeAg was the most sensitive one produced highest O.D values with increasing of sera dilution upto 1:200 in comparison with the other 2 antigens. The fractionation of tested antigens using SDS-PAGE revealed bands in the range of (187-17; 165-15 and 135-28) $\mathrm{kDa}$ for ESAg, PeAg and EEAg respectively.

The ESAg gave seven bands corresponding to M.W standard at the level of 187,115 , $80,67,43,30 \& 17 \mathrm{kDa}$. Eight protein bands were detected in fractionated PeAg correlated to M.W standard at the level of 165,126 , 111, $67 \mathrm{KDa}, 54,45,20$, \& $15 \mathrm{kDa}$. F

The fractionation of EEAg revealed six bands corresponding to M.W standard at the level of 135, 105, 80, 67, 43 \& $28 \mathrm{kDa}$.

Statistical analysis: Data were tabulated and analyzed.

Details are shown in tables $(1,2, \& 3)$ and figures $(1,2 \& 3)$

Table 1: Diagnostic value of tested T. vitulorum antigens versus known infected sera.

\begin{tabular}{|c|c|c|c|c|c|}
\hline \multirow{2}{*}{\multicolumn{2}{|c|}{ EPG of the inspected animals' feces }} & \multirow{2}{*}{$\begin{array}{l}\text { Serum dilu- } \\
\text { tion }\end{array}$} & \multicolumn{3}{|c|}{ Mean ELISA O.D versus } \\
\hline & & & ESAg & $\mathrm{PeAg}$ & EEAg \\
\hline \multirow{6}{*}{$\begin{array}{l}\text { Infected buffaloes } \\
\text { ( } \mathrm{n}=5 \text { animal/group) }\end{array}$} & \multirow{2}{*}{$<300$} & $1: 100$ & 0.396 & 0.482 & 0.333 \\
\hline & & $1: 200$ & 0.311 & 0.441 & 0.302 \\
\hline & \multirow{2}{*}{$\geq 300-500$} & $1: 100$ & 0.511 & 0.593 & 0.442 \\
\hline & & $1: 200$ & 0.438 & 0.522 & 0.408 \\
\hline & \multirow{2}{*}{$>500$} & $1: 100$ & 0.565 & 0.683 & 0.501 \\
\hline & & $1: 200$ & 0.488 & 0.579 & 0.416 \\
\hline \multirow{6}{*}{$\begin{array}{c}\text { Infected buffalo } \\
\text { calves } \\
(n=5 \text { animal/group) }\end{array}$} & \multirow{2}{*}{$<1000$} & $1: 100$ & 0.655 & 0.893 & 0.522 \\
\hline & & $1: 200$ & 0.529 & 0.799 & 0.418 \\
\hline & \multirow{2}{*}{$\geq 1000-2000$} & $1: 100$ & 0.712 & 1.012 & 0.596 \\
\hline & & $1: 200$ & 0.603 & 0.867 & 0.525 \\
\hline & \multirow{2}{*}{$>2000$} & $1: 100$ & 0.748 & 1.133 & 0.623 \\
\hline & & $1: 200$ & 0.611 & 0.977 & 0.558 \\
\hline \multirow{4}{*}{$\begin{array}{c}\text { Control } \\
(\mathrm{n}=5 \mathrm{animal} / \text { group })\end{array}$} & \multirow{2}{*}{ Buffaloes } & 1: 100 & 0.110 & 0.103 & 0.106 \\
\hline & & $1: 200$ & 0.093 & 0.089 & 0.091 \\
\hline & \multirow{2}{*}{$\begin{array}{l}\text { Buffalo } \\
\text { calves }\end{array}$} & $1: 100$ & 0.091 & 0.096 & 0.102 \\
\hline & & $1: 200$ & 0.083 & 0.076 & 0.087 \\
\hline
\end{tabular}


Table 2: Protein fractions characteristic to different $T$. vitulorum antigens using Commassie stain SDS-PAGE

\begin{tabular}{|l|c:c|c|}
\hline MW Marker & ESAg & peAg & EEAg \\
\hline 230 & 187 & 165 & 135 \\
\hline 150 & 115 & 126 & 105 \\
\hline 100 & 80 & 111 & 80 \\
\hline 80 & 67 & 67 & 67 \\
\hline 60 & 43 & 54 & 43 \\
\hline 50 & 30 & 45 & 28 \\
\hline 30 & 17 & 20 & \\
\hline 25 & & 15 & \\
\hline 20 & & & \\
\hline
\end{tabular}

Table 3: T. vitulorum antigenic fractions reacted specifically versus positive and negative RHIS.

\begin{tabular}{|c|c|c|c|c|c|c|}
\hline \multirow{2}{*}{ Marker } & \multicolumn{2}{|c|}{ ESAg versus } & \multicolumn{2}{c|}{ PeAg versus } & \multicolumn{2}{c|}{ EEAg versus } \\
\cline { 2 - 7 } & +ve RHIS & -ve sera & +ve RHIS & -ve sera & +ve RHIS & -ve sera \\
\hline 230 & 105 & 150 & 126 & & 135 & 150 \\
\hline 150 & 80 & & 105 & & 88 & 25 \\
\hline 100 & 67 & & 74 & & 67 & \\
\hline 80 & 50 & & 67 & & 28 & \\
\hline 60 & 45 & & 31 & & & \\
\hline 50 & 43 & & 11 & & & \\
\hline 40 & 30 & & & & & \\
\hline
\end{tabular}

Testing of the antigens on NC strips versus its own RHIS revealed seven bands of M. W $105,80,67,50,45,43 \& 30 \mathrm{kDa}$, six bands at M.W of 126, 105, 74, 67, 31and $11 \mathrm{kDa}$ and four bands at M.W of $135,88,67 \& 28$ $\mathrm{kDa}$ for $T$. vitulorum ESAg, PeAg and EEAg respectively. It was noticed that the protein band of M.W. $67 \mathrm{kDa}$ was found to be specific for T. vitulorum. Moreover, testing of the T. vitulorum antigens versus control negative serum, some showed reaction toward other non-specific fractions (150 $\mathrm{KDa} \& 25 \mathrm{KDa})$. While after the previous EITB reaction was repeated using sera of $T$. vitulorum infected buffaloes with low and high EPG, sera from previously ELISA diagnosed buffaloes showing no eggs in feces, buffalo calves showing high EPG in feces as well as negative control sera, it was revealed that there was marked reaction of the fractionated antigens towards bands of M.W $105,90,67,19 \& 11 \mathrm{kDa}$ which didn't cross react with the other control sera. It was important to mention that the fraction of 67 $\mathrm{kDa}$ from the fractionated PeAg reflex the more prominent reaction.

\section{Discussion}

Gastrointestinal (GI) parasitism is a major constraint for livestock production causing heavy economic losses to the livestock producers. It plays a crucial role in reducing animal production by lowering the working capacity, growth, body weight and milk yield (Choubisa and Jaroli, 2013). Sometimes, diagnosis $T$. vitulorum was not easy as the larvae migrate in the tissues, remaining as dormant or hypobiotic parasites, transmitted through colostrum and milk, causing disease (severe anemia, diarrhea, weight loss \& anorexia) particularly in buffalo calves (Wickramasinghe et al, 2009).

In the present study, as to evaluation of these antigens on field level versus sera of natural infected buffaloes and their calves, it was found that all $T$. vitulorum antigens were sensitive for detection of (ATv-Ab) in the infected animals' sera but the PeAg appeared as the most sensitive one as it produced the highest O.D values in comparison with the other two antigens. These results agreed with Souza et al. (2004) who reported that the $T$. vitulorum PeAg was more sensitive and specific than the ESAg in the term of detection of highest levels of antibodies in sera of infected buffaloes and buffalo calves. Also, Ferreira and Starke-Buzetti (2005) in Brazil reported that T. vitulorum $\mathrm{PeAg}$ was specific and sensitive for detection of (ATV-Ab) in infected buffaloes and buffalo calves sera. Moreover, Thomas et al. (2016) who used ESAg and EEAg in diagnosis of toxocariasis in India reported that 
these antigens lack sensitivity and specificity to detect infection and showed a high cross reaction with other Ascarid antigens.

In the present study, electrophoretic analysis of the tested $T$. vitulorum antigens revealed 7, 8 \& 6 bands ranged from (187-17), (165-15) and (135-28) kDa for ESAg, PeAg and EEAg respectively. These results agreed with Starke-Buzetti and Ferreira (2006) they reported that fractionation of $T$. vitulorum ESAg revealed 8 bands in range of 190-19 kDa. While Jyoti et al. (2011) who performed in India an electrophoretic analysis of T. vitulorum $\mathrm{PeAg}$ that showed 7 bands of MW 20.3, 43.6, 53.1, 57.4, 66.9, 111.3 and $126.3 \mathrm{kDa}$. Moreover, Ferreira and StarkeBuzetti (2005) reported that $T$. vitulorum PeAg was fractionated into 9 bands that ranged from $165-11 \mathrm{kDa}$.

The variations in the M.W. may refer to the method of antigen preparation, type of the used gel, time and voltage adjusted within the SDS-PAGE. Each T. vitulorum antigen was tested versus its own RHIS to detect the specific protein fraction of each one. Also, Pinelli et al. (2013) stated that western blotting considered more beneficial in identification of specific Toxocara spp. diagnostic or immunogenic protein fractions. The reaction revealed seven bands of M.W 105, $80,67,50,45,43 \& 30 \mathrm{kDa}$, six bands at M.W of 126, 105, 74, 67, 31 and $11 \mathrm{kDa}$ and four bands at M.W of $135,88,67 \& 28 \mathrm{kDa}$ for T. vitulorum ESAg, PeAg and EEAg respectively. Also it was cleared that band of M.W $67 \mathrm{kDa}$ was found to be specific band for $T$. vitulorum. This result agreed with Jyoti et al. (2011) in India who reported that band of $66.9 \mathrm{kDa}$ was found a specific for $T$.

vitulorum. It was important to detect the specific band that can be applicable in diagnosis of $T$. vitulorum infection at field level to avoid the non-specificity and cross reactivity problem. Thus, testing of each $T$. vitulorum antigen versus positive sera of buffaloes and buffalo calves was done. There was marked reaction of the fractionated antigens towards bands of M.W 105, 90, 67, $19 \& 11$
kDa. Also, Jyoti et al. (2011) recorded in India bands of M.W 105, 66.9 and $11 \mathrm{kDa}$ in highly infected buffalo calves sera. But, Ferreira and Starke-Buzetti (2005) detected bands of M.W 165, 112, 88, 76, $31 \& 11 \mathrm{kDa}$ by testing PeAg versus positive calve sera with high and low EPG. Fillaux and Magnaval (2013) reported bands of M.W 190, 110, 90, 64 \& $11 \mathrm{kDa}$ by using ESAg.

\section{Conclusion}

The $67 \mathrm{kDa}$ from the fractionated $\mathrm{PeAg}$ reflex was more prominent reaction with sera of naturally infected animals. This band proved marked sensitivity to detect ATv-Ab even in positive samples of low ELISA/OD and low EPG. This band extracted from $\mathrm{PeAg}$ is specific to diagnose toxocariasis in epidemiological survey and laboratory.

\section{References}

Amerasinghe, PH, Rajapakse, RPVJ, Lloyd, S, Fernando, ST, 1992: Antigen-induced protection against infection with $T$. vitulorum larvae in mice. Parasitol. Res. 78:643-7.

Borecka, A, Gawor, J, Niedworok, M, Sordyl, B, 2010: Occurrence of Toxocara spp. eggs in household environment of children with diagnosed toxocariasis in Łódź voivodeship. Wiad. Parazytol.56, 2:141-4.

Choubisa, SL, Jaroli, V, 2013: Gastrointestinal parasitic infection in diverse species of domestic ruminants inhabiting tribal rural areas of southern Rajasthan. India J. Parasit. Dis. 37, 2:271-5. El-Askalany, MA, Mousa, WM, Abo-El Hadid, SM, Lotfy, HS, 2008: Immune characterization of $T$. canis embryonated egg antigen in experimentally infected rabbits. Egypt. J. Exp. Biol. (Zool.), 4: 131-7.

Ferreira, FP, Starke-Buzetti, WA, 2005: Detection of antibody to T.vitulorum perieneteric fluid antigens $(\mathrm{Pe})$ in the colostrum and serum of buffalo calves and cows by Western blotting. Vet. Parasitol. 129:119-24.

Fillaux, J, Magnaval, JF, 2013: Laboratory diagnosis of human toxocariasis. Vet. Parasitol. 193, 4:327-36.

Goswami, A, Das, D, Laha, R, 2013: Characterization of immunogenic proteins of Cysticercus tenuicollis of goats. Vet. Wld. J. 6, 5:267-70. Jyoti, NK, Singh, PD, Juyal, A, 2011: Identification and characterization of immunodominant antigen(s) of T. vitulorum in buffaloes (Bubalus 
bubalis). Vet. Arhciv. 81:369-78.

Laemmli, UK, 1970: Cleavage of structural proteins during the assembly of the head of Bacteriophage T 4. Nature, 227:680-5.

Liu, P, Cui, J, Liu, RD, Wang, M, Jiang, P, et al, 2015: Protective immunity against Trichinella spiralis infection induced by $\mathrm{TsNd}$ vaccine in mice. Parasites Vectors 180:185-92.

Lowry, OH, Rosenbrough, NJ, Farr, AL, Randall, R, 1951: Protein measurement with the phenol reagent. J. Biol. Chemis. 193:265-75.

Omar, HM, Lewis, LW, 1993: Epidemiology of Toxocara species in Egypt. Brit. Soc. Parasitol. Inst. Biol. 39-47.

Pinelli, E, Roelfsema, JH, Brandes, S, Kortbeek, T, 2013: Detection and identification of $T$. canis DNA in bronchoalveolar lavage of infected mice using a novel real-time PCR. Vet. Parasitol. 193: 337-41.

Rast, L, Toribio, JA, Dhand, NK, Khounsy, S, Windsor, P, 2014: Why are simple control options for Toxocara vitulorum not being implemented by cattle and buffalo smallholder farmers in South-East Asia? Prev. Vet. Med. 113, 2:211-8.

Sultan, K, Omar, M, Desouky, AY, El-Seify, MA, 2015: Molecular and phylogenetic study on Toxocara vitulorum from cattle in the mid-Delta of Egypt. J. Parasit. Dis. 39, 3:584-7.

Souza, EM, Starke, WA, Ferreira, FP, Neves, MF, Machado, RZ, 2004: Humoral immune response of water buffalo monitored with three T. vitulorum antigens. Vet. Parasitol. 122:67-78. Starke-Buzetti, WA, Ferreira, FP, 2006: Characterization of excretory/secretory antigen from T. vitulorum larvae. Ann. N.Y. Acad. Sci. 1026: 210-8.

Strube, C, Heuer, L, Janecek, E, 2013: Toxocara spp. infections in paratenic hosts. Vet. Parasitol.193:375-89.

Tang, B, Liu, M, Wang, L, 2015: Characterization of a high-frequency gene encoding a strongly antigenic cystatin-like protein from Trichinella spiralis at its early invasion stage. Parasites Vectors 8:78-82.

Thomas, D, Jeyathilakan, N, Abdul Basith, S, Senthilkumar, TMA, 2016: In vitro production of $T$. canis excretory-secretory (TES) antigen. J. Parasit. Dis. 40, 3:1038-43.

Towbin, H, Stachelin, T, Gordon, J, 1979: Electrophoretic transfer of protein from poly acrylamide gels to nitrocellulose sheets, procedures and some application. Proc. Natl. Acad. Sci. USA 76:4350-4.

Wickramasinghe, SL, Yatawara, RP, Rajapakse, VJ, Agatsuma, T, 2009: Toxocara vitulorum (Ascaridida: Nematode): Mitochondrial gene content, arrangement and composition compared with other Toxocara species. Mol. Biochem. Parasitol. 166, 89-92.

\section{Explanation of Figures}

Fig. 1: Commassie blue stained SDS-PAGE gel containing fractions of different $T$. vitulorum antigens.

Fig. 2: Protein fractions of T. vitulorum antigens on NC membrane treated versus positive and negative RHIS.

Fig. 3: Protein fractions of T. vitulorum antigens on NC membrane treated versus positive and negative buffalo and buffalo calves sera

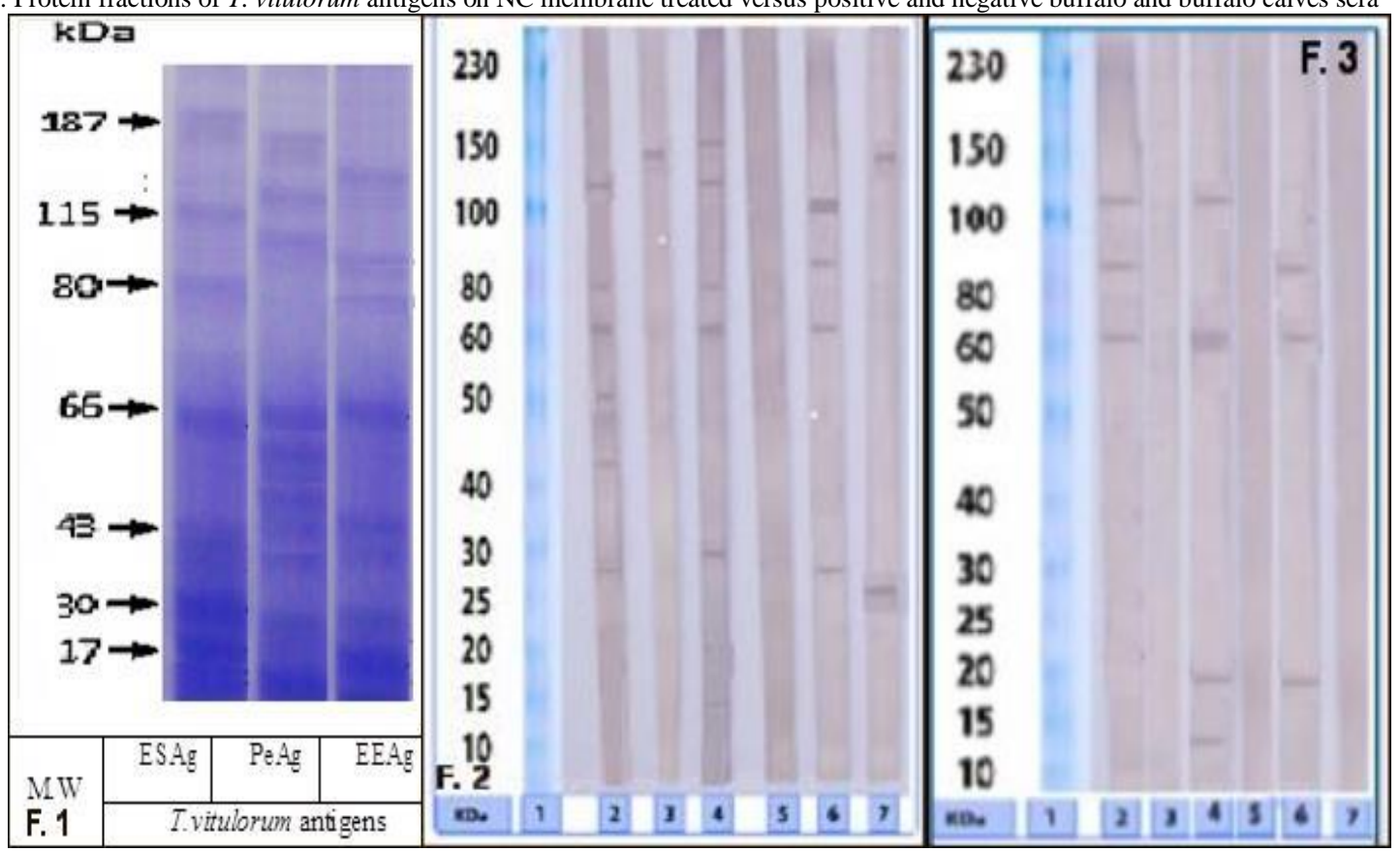

